\title{
Pengaruh Online Customer Review terhadap Purchase Intention dengan Trust sebagai Intervening pada Toko Online Bukalapak di Kota Padang
}

\author{
Yofina Mulyati \\ Grace Gesitera \\ Manajemen, Universitas Dharma Andalas, Indonesia \\ Korespondensi penulis: yofina2017@gmail.com
}

\begin{abstract}
This study aims to determine the effect of online customer reviews (OCR) on purchase intention with trust as an intervening variable in the Bukalapak online store in the City of Padang, West Sumatera, Indonesia. The population in this study were all consumers who shop online at Bukalapak online store in Padang City in 2019 with unknown numbers. The total sample used in this study was 138 people. The sampling method used in this research is nonprobability sampling with an accidental sampling technique. Data analysis in this research used partial least square (PLS). The results obtained from this study indicate that OCR has a significant and positive effect on consumer trust in Bukalapak online stores. OCR and consumer trust have a significant and positive effect on Bukalapak's online purchase intentions, respectively. Then, OCR has a significant and positive effect on their online purchase intentions through consumer trust of Bukalapak online stores in Padang City.
\end{abstract}

Keywords: Bukalapak online store; Consumer trust; Online customer review; Padang City; Purchase intention.

\begin{abstract}
Abstrak. Penelitian ini bertujuan untuk mengetahui pengaruh online customer review (OCR) terhadap niat beli (purchase intention) dengan kepercayaan konsumen (consumer trust) sebagai variabel intervening pada toko online Bukalapak di Kota Padang, Sumatera Barat, Indonesia. Populasi dalam penelitian ini adalah seluruh konsumen yang berbelanja online pada toko online Bukalapak di Kota Padang pada tahun 2019 yang tidak diketahui dengan pasti jumlahnya. Jumlah sampel yang digunakan dalam penelitian ini sebanyak 138 orang. Metode pengambilan sampel menggunakan pendekatan nonprobability sampling dengan teknik accidental sampling. Analisis data dalam penelitian ini menggunakan partial least square (PLS). Hasil yang diperoleh dari penelitian ini mengindikasikan bahwa OCR mempunyai pengaruh positif dan signifikan terhadap kepercayaan konsumen pada toko online Bukalapak. OCR dan kepercayaan konsumen Bukalapak, masing-masing mempunyai pengaruh positif dan signifikan terhadap niat belanja online mereka. Selanjutnya, OCR mempunyai pengaruh positif dan signifikan terhadap niat belanja online konsumen Bukalapak melalui kepercayaan konsumen pada toko online Bukalapak di Kota Padang.
\end{abstract}


Kata Kunci: Kepercayaan konsumen; Kota Padang; Niat beli; Online customer review; Toko online Bukalapak.

Article Info:

Received: October 30, $2019 \quad$ Accepted: March 3, $2020 \quad$ Available Online: March 11, 2020

DOI: http://dx.doi.org/10.30588/jmp.v9i2.538

\section{LATAR BELAKANG}

Dewasa ini, penggunaan internet tidak terbatas hanya pada pemanfaatan informasi yang dapat diakses melalui satu media melainkan dapat juga digunakan sebagai sarana untuk melakukan transaksi yang memunculkan sebuah marketplace baru dan sebuah jaringan bisnis yang luas maupun tidak tebatas oleh tempat dan waktu. Semakin banyaknya pengguna internet di Indonesia akan menjadi pasar yang sangat menjanjikan bagi pelaku industri e-commerce, sehingga bukan hal yang mengherankan apabila bermunculan e-commerce dan marketplace yang besar dengan modal yang fantastis bagi ukuran industri di Indonesia, seperti Matahari Mall, Bukalapak, Lazada, Blibli, Tokopedia, dan lain-lain (Ikranegara, 2017). Kehadiran perdagangan online akan lebih memudahkan konsumen melakukan kegiatan pembelian. Konsumen tidak perlu lagi datang ke toko secara langsung, tetapi mereka hanya perlu mengunjungi situs dalam jaringan internet yang dituju dan menentukan barang/jasa yang mereka butuhkan. Selain itu, online shopping bertujuan untuk meningkatkan niat beli konsumen yang didukung oleh teknologi canggih, sehingga perhatian konsumen dapat dimenangkan, baik dari konten gambar, warna, suara, bentuk, layanan, dan ketersediaan yang dicari. Pada akhirnya, pelaku usaha online dapat memancing niat konsumen untuk membeli produk/jasa dari situs online tersebut (Sophia, 2014).

Tabel 1. Data E-commerce pada Kuartal I Tahun 2019

\begin{tabular}{|c|c|c|c|c|c|c|c|c|}
\hline No & $\begin{array}{c}\text { Toko } \\
\text { Online }\end{array}$ & $\begin{array}{c}\text { Pengunjung } \\
\text { Website } \\
\text { Bulanan } \\
\end{array}$ & $\begin{array}{l}\text { Rangking } \\
\text { AppStore }\end{array}$ & $\begin{array}{l}\text { Ranking } \\
\text { PlayStore }\end{array}$ & Twitter & Instagram & Facebook & Jumlah \\
\hline 1 & Tokopedia & 137.200 .900 & 2 & 2 & 192.100 & 1.148 .500 & 6.049 .900 & 144.591 .400 \\
\hline 2 & Bukalapak & 115.256 .600 & 3 & 4 & 161.500 & 711.700 & 2.423 .200 & 118.553 .000 \\
\hline 3 & Shopee & 74.995 .300 & 1 & 1 & 69.300 & 2.164 .100 & 14.409 .600 & 91.638 .300 \\
\hline 4 & Lazada & 52.044 .500 & 4 & 3 & 365.300 & 1.173 .200 & 28.245 .000 & 81.828 .000 \\
\hline 5 & Blibli & 32.597 .200 & 7 & 6 & 483.300 & 627.400 & 8.244 .800 & 41.952 .700 \\
\hline 6 & JD ID & 10.656 .900 & 5 & 5 & 22.800 & 406.300 & 778.300 & 11.864 .300 \\
\hline
\end{tabular}

Sumber: iprice.co.id (2019).

Bukalapak merupakan salah satu situs jual beli online terbesar di Indonesia. Toko online Bukalapak didirikan pada tahun 2010 (inet.detik.com, 2019). Bukalapak menyediakan sarana penjualan dari konsumen ke konsumen di mana pun. Bukalapak memiliki program untuk memfasilitasi para pelaku Usaha Kecil dan Menengah (UKM) yang ada di Indonesia untuk melakukan transaksi jual beli secara online. Hal ini dikarenakan transaksi online dapat mempermudah UKM dalam menjual produk-produk yang mereka miliki tanpa harus memiliki toko offline. Bukalapak menyediakan beragam jenis produk yang ditawarkan. Keberagaman produk yang ditawarkan oleh Bukalapak tersebut memiliki berbagai kategori, meliputi handphone, sepeda, tablet, aksesoris gadget, 
komputer, laptop, printer/scanner, media penyimpanan data, fashion wanita, fashion pria, aksesoris fashion, peralatan elektronik, audio dan video, perlengkapan rumah tangga, perlengkapan bayi, hingga buku maupun alat musik, dan lain-lain (Anisa, 2019). Dengan berbagai produk yang ditawarkan, Bukalapak bertujuan untuk menciptakan niat beli para calon pembeli. Tabel 1 menunjukkan data e-commerce di Indonesia berdasarkan rata-rata pengunjung website di setiap kuartal, ranking aplikasi, dan peringkat media sosial.

Berdasarkan Tabel 1, situs Bukalapak memiliki pengunjung website per bulan terbanyak kedua dibandingkan toko online lainnya, meskipun untuk rangking appstore ia berada di posisi ketiga, serta pada peringkat playstore ia berada di posisi keempat. Pengunjung Bukalapak melalui Twitter dan Instagram masing-masing di peringkat keempat, sedangkan melalui Facebook, ia berada di peringkat kelima. Hal ini mengindikasikan meskipun website Bukalapak dapat menyajikan secara langsung online customer review (OCR) dan mampu menarik niat belanja online lebih banyak dibandingkan promosi melalui media sosial. Namun, kondisi tersebut belum tentu dapat dipastikan bahwa konsumen akan berbelanja setelah melihat OCR yang diberikan. Hal itu disebabkan OCR dapat mempengaruhi kepercayaan seseorang untuk berniat melakukan belanja online. Kemungkinan itu terlihat dari perkembangan jumlah pengunjung Bukalapak setiap kuartal, yaitu peta e-commerce di Indonesia dengan mengurutkan pemain besar $e$ commerce berdasarkan rata-rata pengunjung di setiap kuartal. Satu tahun terdiri atas empat kuartal.

Tabel 2 menunjukkan data perkembangan pengunjung Bukalapak dari kuartal I tahun 2018 sampai dengan kuartal I tahun 2019. Berdasarkan Tabel 2 tersebut, pengunjung Bukalapak mengalami penurunan pada kuartal II tahun 2018 yang mencapai 8,5\%. Namun, jumlah pengunjung kembali naik pada kuartal III dan kuartal IV tahun 2018. Pengunjung Bukalapak kembali mengalami penurunan pada kuartal I tahun 2019 sebesar $0,4 \%$. Hal ini mengindikasikan bahwa niat belanja online cenderung mengalami perubahan yang dapat dindikasikan bahwa salah satu penyebabnya adalah OCR yang diberikan Bukalapak, sehingga faktor tersebut dapat mengubah kepercayaan konsumen untuk berniat dalam belanja online.

Tabel 2. Pengunjung Bukalapak Periode Kuartal I Tahun 2018 sampai dengan Kuartal I Tahun 2019

\begin{tabular}{cccc}
\hline No & Kuartal/Tahun & Jumlah Pengunjung & Persentase Perubahan \\
\hline 1 & QI 2018 & 96.000 .000 & - \\
\hline 2 & QII 2018 & 87.812 .200 & $(8,5)$ \\
\hline 3 & QIII 2018 & 98.814 .330 & 12,5 \\
\hline 4 & QIV 2018 & 119.022 .270 & 20,5 \\
\hline 5 & QI 2019 & 118.553 .000 & $(0,4)$ \\
\hline
\end{tabular}

Keterangan: Q = kuartal.

Sumber: iprice.co.id (2019).

Menurut Ling, Chai, dan Piew (2010), purchase intention (niat beli) online adalah sebuah situasi ketika seorang pelanggan bersedia dan berniat untuk terlibat dalam transaksi pembelian online. Pada dasarnya, niat beli konsumen merupakan faktor pendorong dalam pengambilan keputusan pembelian terhadap suatu produk. Selanjutnya, Setiadi (2010) mengemukakan bahwa niat beli ialah salah satu tahapan dalam proses adopsi 
ketika konsumen tertarik untuk mencari informasi tersebut. Sebaliknya, Kerin, Lau, Hartley, dan Rudelius (2009) menyatakan bahwa niat beli ialah kecenderungan seorang konsumen dalam membeli suatu merek atau mengambil sebuah tindakan yang berhubungan dengan pembelian. Dari ketiga pendapat tersebut, purchase intention atau niat beli merupakan pernyataan mental konsumen yang merefleksikan rencana pembelian sejumlah produk dengan merek tertentu. Niat beli konsumen sangat diperlukan oleh para pemasar untuk memahami kecenderungan konsumen membeli suatu produk. Baik pemasar maupun ahli ekonomi menggunakan variabel niat beli untuk memprediksi perilaku konsumen di masa yang akan datang.

Niat beli konsumen muncul karena beberapa faktor. Salah satu faktor yang dapat mempengaruhi timbulnya niat beli adalah online customer review (OCR) atau juga bisa disebut sebagai electronic word of mouth (eWOM), yaitu salah satu fitur yang menarik banyak perhatian kalangan akademisi maupun masyarakat sebagai salah satu faktor yang paling berpengaruh dalam menentukan keputusan pembelian konsumen (Farki, Baihaqi, \& Wibawa, 2016). OCR mengacu pada konten buatan pengguna yang diposting pada situs belanja online maupun situs web pihak ketiga. Hal ini menunjukkan bahwa seseorang dapat mendasarkan jumlah review sebagai indikator popularitas produk atau nilai suatu produk yang akan mempengaruhi niat untuk membeli suatu produk.

Dalam dunia e-commerce, konsumen dapat menemukan banyak sekali situs penjual dan tidak semua penjual tersebut menyajikan barang dengan merek asli. Para penjual terkadang menjual barang tiruan dengan merek terkenal. Dari produk tiruan tersebut, ada yang memiliki kualitas baik dengan harga yang tinggi dan ada juga yang menjualnya dengan kualitas biasa dengan harga relatif murah dengan tampilan seperti merek asli, sehingga hal itu membuat konsumen memahaminya sebagai barang asli. Berbelanja secara online memerlukan kepercayaan karena tidak mudah untuk membangun kepercayaan diantara penjual dan pembeli online. Kepercayaan pelanggan mempengaruhi niat pembelian produk. Kepercayaan di antara pembeli dan penjual sangat diperlukan dalam transaksi online (Picaully, 2018).

Menurut Baskara dan Haryadi (2014), faktor sangat penting yang dapat mempengaruhi pembelian online adalah kepercayaan konsumen (consumer trust). Kepercayaan konsumen menjadi faktor kunci dalam setiap transaksi jual beli online. Dengan adanya kepercayaan, maka konsumen cenderung akan melakukan pembelian produk, karena pembelian secara online memiliki karakteristik sangat berbeda dengan pembelian konvensional. Dalam pembelian online, calon pembeli tidak dapat melihat dan menyentuh produk secara fisik dan hanya bisa melihatnya melalui gambar yang terpasang pada website toko online. Kepercayaan konsumen merupakan pondasi kuat untuk menentukan sukses atau tidaknya $e$-commerce ke depan. Untuk menarik niat konsumen berkunjung dan bertransaksi melalui situsnya, pelaku e-commerce harus mampu membangun kepercayaan yang tinggi pada diri calon pembeli produknya.

Ketika seorang konsumen ingin melakukan transaksi pembelian secara online, maka hal utama yang mereka perhatikan adalah reputasi pelapak yang tersedia di situs Bukalapak, apakah mereka dapat dipercaya atau tidak. Langkah tersebut dapat dilakukan dengan mengecek testimoni pembeli yang pernah berbelanja di situsnya. Bukalapak sendiri memunculkan tanda khusus bagi pelapak yang produknya sering dibeli konsumen. Konsumen selalu berharap bahwa uang yang dikirimkannya untuk membayar transaksi tidak hilang begitu saja, tetapi keputusan pembelian tersebut mendapatkan 
balasan berupa produk yang sesuai dengan keinginannya dan sesuai apa yang ditampilkan maupun dijelaskan oleh penjual pada situs belanjanya.

Berikut ini adalah beberapa informasi tentang pengalaman berbelanja yang terkait kepercayaan pada situs belanja online Bukalapak. Berdasarkan informasi yang disampaikan oleh Rusli (2015) diketahui bahwa kebijakan Bukalapak yang telah dibuat bertujuan untuk meningkatkan kepercayaan calon pembeli. Namun, hal itu berbeda dengan apa yang sesungguhnya terjadi. Contohnya, kasus tidak menyenangkan pernah dialami oleh seorang konsumen pada tahun 2015. Ia membeli microSD 64GB seharga Rp250.000 pada pelapak di situs Bukalapak pada tanggal 2 Juli 2015. Setelah barang yang dipesan datang pada tanggal 6 Juli 2015, barang yang terkirim tidak sesuai dengan pesanannya. Akhirnya, konsumen melakukan komplain dan retur pembelian dengan persyaratan yang diajukan oleh Bukalapak, meskipun ia merasa kecewa (Rusli, 2015). Hal ini mengindikasikan bahwa kepercayaan konsumen terhadap Bukalapak akan menurun akibat mitra Bukalapak (pelapak) tidak dapat memberikan layanan sesuai dengan yang diharapkan konsumen. Selanjutnya, hasil wawancara awal yang dilakukan peneliti pada bulan Mei 2019 terhadap 30 konsumen yang berbelanja online pada situs Bukalapak di Kota Padang mengutarakan berbagai macam keluhan yang tersaji pada Tabel 3.

Tabel 3. Keluhan Konsumen di Kota Padang yang Berbelanja Online pada Situs Bukalapak

\begin{tabular}{clccc}
\hline No & \multicolumn{1}{c}{ Keluhan Konsumen } & $\begin{array}{c}\text { Tidak } \\
\text { Setuju }\end{array}$ & Setuju & $\begin{array}{c}\text { Persentase } \\
\text { Setuju }\end{array}$ \\
\hline 1 & $\begin{array}{l}\text { Review pada pelapak Bukalapak menampilkan } \\
\text { keluhan barang yang tidak dikirimkan. }\end{array}$ & 11 & 19 & 63,3 \\
\hline 2 & $\begin{array}{l}\text { Review pada pelapak Bukalapak menampilkan } \\
\text { lambatnya respon terhadap komplain. }\end{array}$ & 8 & 22 & 73,3 \\
\hline 3 & $\begin{array}{l}\text { Review pada pelapak Bukalapak menampilkan } \\
\text { barang yang dibeli tidak sesuai pesanan. }\end{array}$ & 14 & 16 & 53,3 \\
\hline $\begin{array}{l}\text { Review pada pelapak Bukalapak menampilkan } \\
\text { ada pelapak yang menipu konsumen untuk } \\
\text { barang yang dibeli (barang yang dikirimkan } \\
\text { tidak sesuai dengan yang dipesan). }\end{array}$ & 13 & 17 & 56,7 \\
\hline 5 & $\begin{array}{l}\text { Peringkat rating pelapak tidak dapat menjamin } \\
\text { tidak akan terjadi penipuan di Bukalapak. }\end{array}$ & 7 & 23 & 76,7 \\
\hline 6 & $\begin{array}{l}\text { Produk yang dikirim pelapak tidak sesuai } \\
\text { dengan iklan yang ditampilkan. }\end{array}$ & 11 & 19 & 63,3 \\
\hline St
\end{tabular}

Sumber: Hasil survei awal dengan wawancara langsung (n=30), Mei 2019.

Berdasarkan Tabel 3 tersebut, dari segi OCR didapatkan 19 orang $(63,3 \%)$ konsumen setuju review pada pelapak Bukalapak untuk menampilkan keluhan adanya barang yang tidak dikirimkan dan 22 orang $(73,3 \%)$ setuju review pada pelapak Bukalapak untuk menampilkan lambatnya respon komplain. Selanjutnya, dari segi rating, 23 orang (76,7\%) konsumen yang berbelanja online di Bukalapak Kota Padang mengatakan setuju agar peringkat atau rating pelapak tidak dapat menjamin tindak penipuan di Bukalapak tidak akan terjadi. Selain itu, dari segi iklan 19 orang $(63,3 \%)$ konsumen juga setuju produk yang dikirim pelapak ada yang tidak sesuai dengan iklan yang ditampilkan. Hasil survei ini mengindikasikan banyaknya komplain atau keluhan konsumen yang berbelanja online di Bukalapak Kota Padang membuat mereka merasa kecewa 
berbelanja online di Bukalapak, sehingga hal ini dapat mempengaruhi penjualan Bukalapak dan mengurangi niat belanja akibat kepercayaan yang menurun.

Menurut Ling et al. (2010), jika pengalaman pembelian online sebelumnya dapat memperlihatkan hasil yang memuaskan, maka kondisi itu akan menyebabkan pelanggan untuk terus berbelanja online dalam waktu panjang. Sayangnya, jika pengalaman masa lalu bersifat negatif, konsumen enggan untuk terlibat lebih jauh dalam belanja online di masa depan. Pengalaman belanja online konsumen yang buruk akan mempengaruhi review agar orang lain dapat melihat apa yang dilakukan toko penjual terhadap produk yang diinginkan, sekaligus konsumen dapat memberikan rating terhadap layanan toko online tersebut.

Berdasarkan latar belakang masalah yang telah diuraikan, maka permasalahan dalam penelitian ini adalah bagaimana pengaruh online customer review (OCR) terhadap kepercayaan konsumen dan bagaimana pula pengaruh keduanya terhadap niat beli konsumen di toko online, serta bagaimana pengaruh OCR terhadap niat beli konsumen di toko online melalui kepercayaan mereka tersebut. Dari uraian latar belakang dan permasalahan tersebut, maka tujuan penelitian ini adalah untuk mengetahui pengaruh OCR terhadap kepercayaan konsumen pada toko online Bukalapak, pengaruh OCR dan kepercayaan konsumen terhadap niat beli mereka di toko online Bukalapak, dan pengaruh OCR terhadap niat beli konsumen di toko online Bukalapak melalui kepercayaan mereka.

\section{LANDASAN TEORI}

\section{Niat Beli (Purchase Intention)}

Pada dasarnya, niat beli konsumen (purchase intention) merupakan faktor pendorong dalam pengambilaan keputusan pembelian terhadap suatu produk. Zafar dan Rafique (2013) menyampaikan niat beli konsumen adalah hasrat dan kecenderungan konsumen untuk membeli produk yang diiklankan karena ada kemungkinan konsumen membeli produk tersebut di masa yang akan datang. Kotler dan Keller (2016) menjelaskan bahwa niat atau intensi merupakan suatu dorongan atau rangsangan internal yang kuat dalam memotivasi tindakan seseorang dan dorongan tersebut dipengaruhi oleh stimulus dan perasaan positif akan produk.

Khan, Naumann, dan Williams (2012) menyatakan bahwa niat beli dapat didefinisikan sebagai niat seseorang untuk membeli merek tertentu yang telah mereka pilih untuk diri mereka sendiri setelah mengevaluasinya. Konsumen dapat mengukur variabel niat beli. Misalnya, mempertimbangkan merek untuk pembelian dan mengharapkan untuk membeli produk tersebut di masa yang akan datang. Simamora (2011) menyatakan bahwa niat beli konsumen terhadap suatu produk timbul karena adanya dasar kepercayaan terhadap produk yang diiringi dengan kemampuan untuk membeli produk tersebut. Selain itu, niat beli konsumen terhadap produk juga dapat terjadi dengan adanya pengaruh orang lain yang mereka percaya. Di sisi lain, Penitasari (2017) menyatakan bahwa niat beli terbentuk dari sikap konsumen terhadap suatu produk. Niat beli tersebut berasal dari kepercayaan konsumen terhadap kualitas produk. Semakin rendah kepercayaan konsumen terhadap suatu produk akan menyebabkan menurunnya niat beli konsumen (Penitasari, 2017). 


\section{Online Customer Review (OCR)}

Online customer review (OCR) adalah ulasan yang diberikan oleh konsumen terkait dengan informasi atas evaluasi suatu produk tentang berbagai macam aspek. Dengan informasi tersebut, konsumen bisa mendapatkan kualitas produk yang dicari dari ulasan dan pengalaman yang ditulis oleh konsumen lain yang telah membeli produk dari penjual online sebelumnya (Mo \& Fan, 2015). Konsumen biasanya mencari informasi yang berkualitas saat memutuskan membeli produk. Dengan peningkatan popularitas dari internet, OCR menjadi sumber penting yang dicari oleh konsumen untuk mengetahui kualitas suatu produk (Zhu, 2010).

OCR bisa berisi informasi tentang hal-hal yang bersifat positif maupun negatif tentang produk atau pun perusahaan (penjual) dan dibuat oleh para konsumen via internet (Park \& Lee, 2009), serta menggambarkan karakteristik (misalnya keuntungan dan kerugian) dari suatu produk (Lackermair, Kailer, \& Kanmaz, 2013). Hasil penelitian menunjukkan bahwa sugesti yang diberikan oleh konsumen yang telah menggunakan produk melalui pemberian informasi tentang produk menjadi salah satu evaluasi yang bernilai untuk pembuatan keputusan oleh calon konsumen atas produk tersebut (Liu, 2006).

OCR adalah salah satu bentuk word of mouth communication pada penjualan online (Filieri, 2014), yaitu calon pembeli mendapatkan informasi tentang produk dari konsumen yang telah mendapatkan manfaat produk tersebut sebelumnya. Electronic word of mouth (e-WOM) didefinisikan sebagai pernyataan baik atau positif maupun kriteria bagi orang yang akan membeli produk, orang yang telah membeli produk, atau siapa pun yang ingin berkomentar terkait dengan sebuah produk (Hennig-Thurau, Gwinner, Walsh, \& Gremler, 2004). Akibatnya, konsumen lebih mudah untuk mencari perbandingan dengan produk sejenis yang dijual pada penjual online lain. Hal tersebut terjadi karena penggunaan digital marketing yang semakin intensif, sehingga informasi tersebut dapat memberikan keuntungan bagi konsumen, yaitu mereka tidak harus mengunjungi penjual yang berbeda secara langsung (Yasmin, Tasneem, \& Fatema, 2015).

Apabila konsumen sulit menduga kualitas suatu produk atau dugaan atas kriteria produk adalah ambigu, maka ketersediaan informasi menjadi salah satu penentu dalam membuat keputusan. Informasi tersebut dapat diperoleh dari review konsumen lain yang telah membeli atau menggunakan produk tersebut sebelumnya. Calon konsumen seharusnya mencari informasi yang cukup tentang produk, sebelum ia melakukan pembelian. Hal itu dikarenakan calon konsumen belum memiliki pengalaman tentang produk tersebut (Klein dalam Auliya, Umam, \& Prastiwi, 2017). Kualitas informasi yang terdapat dalam review memberikan efek pada persepsi kredibilitas. Faktanya, kualitas informasi dipercaya menjadi salah satu sinyal kebenaran dalam OCR (Filieri, 2014). Saat berbelanja online, konsumen menghadapi banyak pilihan. Di sisi lain, konsumen hanya memiliki sedikit informasi langsung tentang produk, karena mereka tidak dapat menyentuh atau merasakan produknya. Untuk mengatasi kelemahan ini, maka OCR menyediakan informasi yang relevan kepada konsumen (Chou, 2012). Relevansi informasi tersebut dapat terjadi, karena OCR dilakukan secara sukarela oleh konsumen yang telah membeli produk tersebut sebelumnya.

Salah satu kekurangan pada OCR, seperti yang diungkapkan oleh Bakos dalam Auliya et al. (2017), yaitu hubungan antara pengirim dan penerima OCR adalah orangorang yang saling kenal, sehingga informasi yang dihasilkan menjadi lebih terpercaya. 
Sebaliknya, ketika hubungan antara pengirim dan penerima OCR adalah orang-orang yang tidak saling kenal, maka kemungkinan untuk mendapatkan informasi yang tidak akurat menjadi lebih tinggi. OCR terjadi tanpa ada pertemuan langsung antara pemberi informasi dengan penerimanya. Dengan jumlah konsumen yang banyak, maka filter pada ulasan produk atau jasa dalam konteks online menjadi lebih sulit (M. Lee \& Youn, 2009).

Konsumen yang mempunyai pengalaman penggunaan internet akan menggunakan saluran online untuk mengumpulkan informasi tentang produk. Hal itu dikarenakan biaya untuk mengumpulkan informasi cenderung lebih murah daripada menggunakan saluran konvensional (Cook \& Coupey dalam Auliya et al., 2017). Hal tersebut disebabkan konsumen mudah mencari OCR, karena ulasan konsumen secara online biasanya disediakan dalam bentuk format teks yang mudah diambil (K. Lee \& Koo, 2012). Namun, OCR dapat merepresentasikan preferensi konsumen (Zhu \& Zhang, 2010). Konsumen mencari informasi produk dari ulasan di internet, karena mereka kesulitan untuk mendapatkan informasi terkait produk yang akan dibeli dari sumber-sumber selain internet. Selain dari internet, salah satu kesulitan mendapatkan informasi tersebut adalah waktu yang dimiliki oleh konsumen. Konsumen akan membutuhkan lebih banyak waktu, apabila mereka mencarinya tidak melalui internet. Dari uraian tersebut, hipotesis kesatu $(\mathrm{H} 1)$ dan kedua $(\mathrm{H} 2)$ yang diajukan adalah:

\section{H1: Online customer review (OCR) berpengaruh terhadap kepercayaan konsu- men pada toko online Bukalapak di Kota Padang.}

\section{H2: Online customer review (OCR) berpengaruh terhadap niat belanja online konsumen di toko online Bukalapak di Kota Padang.}

\section{Kepercayaan Konsumen (Consumer Trust)}

Widyawati (2008) menyatakan bahwa kepercayaan (trust), sikap, dan perilaku terkait dengan konsep atribut produk (product attributes), sedangkan atribut produk adalah karakteristik suatu produk. Umumnya, konsumen memiliki kepercayaan terhadap atribut suatu produk. Kepercayaan dan pengetahuan konsumen menunjukkan bahwa produk tersebut memiliki berbagai atribut dan manfaat. Perusahaan perlu memahami atribut suatu produk yang diketahui konsumen dan atribut mana yang digunakan untuk mengevaluasinya, sehingga pengetahuan tersebut berguna untuk mengomunikasikan atribut produk kepada konsumen (Widyawati, 2008).

Menurut Sumarwan (2011), kepercayaan konsumen terhadap produk yang dilihat dari atribut dan manfaatnya dapat menggambarkan persepsi atau penilaian konsumen atas kepercayaannya terhadap produk tersebut. Oleh karena itu, kepercayaan masingmasing konsuman terhadap produk dapat berbeda-beda. Menurut Costabile dalam Ferrinadewi (2008), kepercayaan konsumen diartikan sebagai persepsi atas kekuatan dari sudut pandang konsumen yang didasarkan pada pengalaman transaksi atau interaksi yang dicirikan oleh terpenuhinya harapan akan kinerja produk dan kepuasan.

Mowen dan Minor (2002) menjelaskan bahwa kepercayaan konsumen adalah semua pengetahuan yang dimiliki oleh konsumen dan semua kesimpulan yang dibuatnya tentang obyek, atribut, dan manfaatnya. Obyek (objects) dapat berupa produk, orang, perusahaan, dan segala sesuatu yang dipercaya dan disakpi orang. Atribut (attributes) adalah karakteristik atau fitur yang dapat dimiliki atau tidak dimiliki oleh suatu 
obyek, sedangkan manfaat (benefits) adalah hasil positif yang dapat diperoleh konsumen. Secara umum, kepercayaan dipandang sebagai unsur mendasar bagi keberhasilan sebuah hubungan.

Menurut Sumarwan (2011), kepercayaan menunjukkan sebuah kekuatan bahwa suatu produk memiliki atribut tertentu. Konsumen akan mengungkapkan kepercayaan terhadap berbagai atribut yang dimiliki suatu merek atau produk yang dievaluasinya. Konsumen akan memperhatikan merek suatu produk, ketika ia mengevaluasi atribut yang dimiliki oleh masing-masing merek tersebut. Kepercayaan sering disebut object attribute linkages, yaitu kepercayaan konsumen memiliki hubungan antara obyek dengan atributnya yang relavan. Dari uraian tersebut, hipotesis ketiga (H3) dan keempat (H4) yang diajukan dalam penelitian ini adalah:

\section{H3: Kepercayaan konsumen berpengaruh terhadap niat belanja online mereka di toko online Bukalapak di Kota Padang.}

H4: Online customer review (OCR) berpengaruh terhadap niat belanja online konsumen melalui kepercayaan konsumen di toko online Bukalapak di Kota Padang.

\section{Rerangka Konseptual}

Review dapat mengurangi rasa ketidakpastian konsumen dengan memberikan gambaran yang lebih nyata terhadap suatu produk maupun jasa yang ditawarkan oleh produsen. Selain itu, customer review merupakan sumber informasi utama bagi konsumen. Informasi yang diperoleh konsumen akan menimbulkan opini terhadap suatu produk maupun layanan jasa, sehingga hal tersebut dapat memicu munculnya niat beli konsumen. OCR dapat mempengaruhi kepercayaan konsumen. Semakin baik review yang diberikan oleh konsumen lain terhadap suatu produk, maka kepercayaan konsumen terhadap produk tersebut juga semakin meningkat. Konten review yang baik dapat menjadi informasi penting yang menimbulkan kepercayaan konsumen terhadap produk atau layanan jasa yang ditawarkan. Berdasarkan permasalahan, tujuan penelitian, dan kajian teori yang telah dikemukakan tersebut, maka rerangka pemikiran yang mendasari penelitian ini digambarkan dalam model penelitian pada Gambar 1.

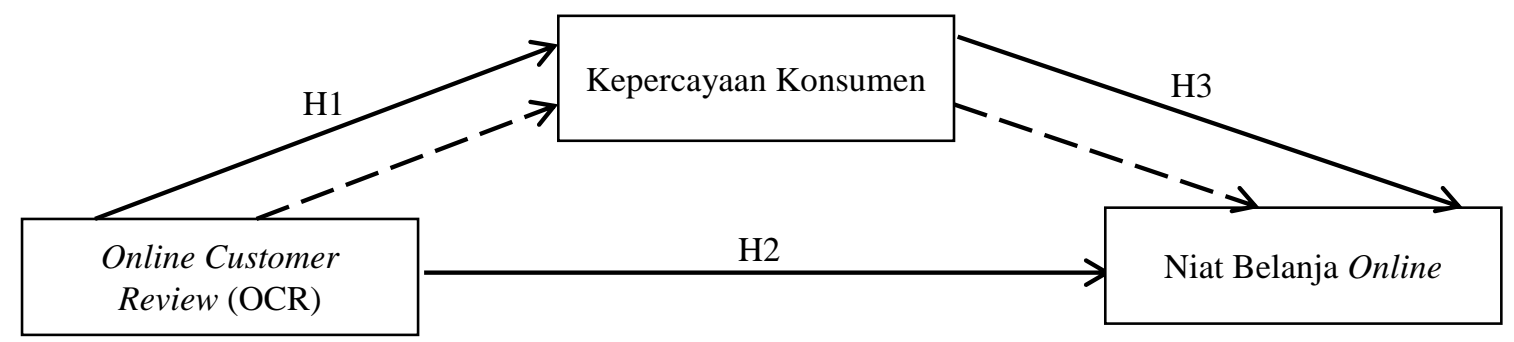

Keterangan:

$--\longrightarrow=\mathrm{H} 4$

\section{Gambar 1. Model Penelitian}

\section{METODE PENELITIAN}

\section{Jenis dan Sampel Penelitian}


Jenis penelitian yang digunakan dalam penelitian ini adalah kuantitatif. Populasi penelitian ini adalah seluruh konsumen yang berbelanja online di toko online Bukalapak di Kota Padang pada tahun 2019 yang tidak diketahui dengan pasti jumlahnya. Selanjutnya, jumlah sampel ditentukan dengan menggunakan pendekatan rumus Chocran dalam Sarwono (2012) yang diformulasikan pada persamaan [1].

$$
n_{0}=\frac{z^{2} p q}{e^{2}}
$$

Keterangan:

$n_{0}=$ Ukuran sampel.

$\mathrm{Z}^{2}=$ Abscissa (jarak tegak lurus suatu titik dari sumbu-y) kurva normal yang memotong area sisi (tails) atau 1-tingkat kepercayaan 95\%, maka $\mathrm{Z}$ sebesar $=1,96$.

$\mathrm{e} \quad=$ Tingkat ketepatan yang diinginkan $=100 \%-95 \%=5 \%$ atau 0,05 .

$\mathrm{p} \quad=$ Estimasi proporsi suatu atribut yang ada dalam populasi $=10 \%$ atau 0,1 .

$\mathrm{q}=1-\mathrm{p}=1-0,1=0,9$.

Berdasarkan rumus pada persamaan [1] tersebut, maka perhitungan jumlah sampel yang digunakan dalam penelitian ini adalah:

$$
n_{0}=\frac{\left(1,96^{2}\right)(0,1)(0,9)}{0,05^{2}}=138,29 \text { dibulatkan menjadi } 138
$$

Berdasarkan hasil perhitungan jumlah sampel tersebut, maka jumlah sampel minimal sebanyak 138 orang konsumen yang berbelanja di toko online Bukalapak di Kota Padang pada tahun 2019. Metode pengambilan sampel menggunakan pendekatan nonprobability sampling dengan teknik accidental sampling (Sugiyono, 2014), sedangkan analisis data yang digunakan adalah Partial Least Square (PLS).

\section{Definisi Operasional Variabel}

Penelitian ini menggunakan tiga variabel dengan rumusan definisi operasional, indikator, dan skala pengukuran yang diuraikan pada Tabel 4.

\section{HASIL DAN PEMBAHASAN}

\section{Gambaran Karakteristik Responden}

Dari 138 responden, mayoritas konsumen yang berbelanja di toko online Bukalapak di Kota Padang memiliki rentang usia dari 23 sampai 28 tahun, yaitu sebanyak 61 orang $(44,2 \%)$, serta usia antara 17 sampai 22 tahun sebanyak 33 orang (23,9\%). Pada umumnya, jumlah responden hampir seimbang antara laki-laki dan perempuan, masingmasing sebanyak 66 orang laki-laki $(47,8 \%)$ dan 72 orang perempuan $(52,2 \%)$. Dari total keseluruhan responden, yang memiliki pendidikan terakhir terbanyak adalah SMA sebanyak 77 orang $(55,8 \%)$ dan yang paling sedikit berpendidikan terakhir pascasarjana (S2) sebanyak 8 orang $(5,8 \%)$.

Secara umum, responden berpenghasilan antara Rp1.000.000 hingga Rp2.000.000 sebanyak 70 orang (50,7\%), kisaran Rp2.000.001 hingga Rp3.000.000 sebanyak 39 orang $(28,3 \%)$, dan yang paling sedikit berbelanja online adalah mereka yang memiliki 
penghasilan antara Rp3.000.001 hingga Rp4.000.000 sebanyak 12 orang (8,7\%). Mayoritas responden adalah pelajar/mahasiswa sebanyak 54 orang $(39,1 \%)$, pegawai swasta sebanyak 33 orang $(23,9 \%)$, dan yang paling sedikit adalah ibu rumah tangga, yaitu 1 orang $(0,7 \%)$ dari keseluruhan jumlah responden.

Tabel 4. Definisi Operasional Variabel Penelitian

\begin{tabular}{|c|c|c|c|c|}
\hline No & Variabel & Defenisi Variabel & Indikator/Referensi & Skala \\
\hline 1 & $\begin{array}{l}\text { Online Customer } \\
\text { Review (OCR) }\end{array}$ & $\begin{array}{l}\text { Online customer review (OCR) } \\
\text { adalah ulasan yang diberikan oleh } \\
\text { konsumen terkait dengan informasi } \\
\text { hasil evaluasi pembelian/pengguna- } \\
\text { an suatu produk tentang berbagai } \\
\text { macam aspek. Dengan adanya infor- } \\
\text { masi ini, konsumen bisa mendapat- } \\
\text { kan kualitas produk yang diinginkan } \\
\text { dari ulasan dan pengalaman yang } \\
\text { ditulis oleh konsumen yang telah } \\
\text { membeli produk dari penjual online } \\
\text { sebelumnya (Mo \& Fan, 2015). }\end{array}$ & $\begin{array}{l}\text { - Perceived usefulness } \\
\text { - Perceived enjoyment } \\
\text { - Perceived control. } \\
\text { Elwalda \& Lü (2014), } \\
\text { Farki et al. }(2016), \text { dan } \\
\text { Ichsan (2018). }\end{array}$ & Likert \\
\hline 2 & $\begin{array}{l}\text { Kepercayaan } \\
\text { Konsumen } \\
\text { (Consumer } \\
\text { Trust) }\end{array}$ & $\begin{array}{l}\text { Kepercayaan konsumen adalah } \\
\text { semua pengetahuan yang dimiliki } \\
\text { konsumen dan semua kesimpulan } \\
\text { yang dibuatnya tentang obyek, atri- } \\
\text { but dan manfaatnya (Mowen \& } \\
\text { Minor, 2002). }\end{array}$ & $\begin{array}{l}\text { - Keamanan } \\
\text { - } \quad \text { Privasi } \\
\text { - Keandalan } \\
\text { Ling et al (2010), } \\
\text { Ikranegara (2017), dan } \\
\text { Elwalda \& Lü (2014). }\end{array}$ & Likert \\
\hline 3 & $\begin{array}{l}\text { Niat Belanja } \\
\text { Online (Online } \\
\text { Purchase } \\
\text { Intention) }\end{array}$ & $\begin{array}{l}\text { Niat beli atau niat belanja online } \\
\text { ialah salah satu tahapan dalam } \\
\text { proses adopsi, ketika konsumen } \\
\text { tertarik untuk mencari informasi } \\
\text { tersebut (Setiadi, 2010). Dalam } \\
\text { penelitian ini, niat beli diproksikan } \\
\text { dengan niat belanja online. }\end{array}$ & $\begin{array}{l}\text { - } \quad \text { Niat transaksional } \\
\text { - } \quad \text { Niat referensial } \\
\text { - } \quad \text { Niat preferensial } \\
\text { - } \quad \text { Niat eksploratif } \\
\text { Ferdinand (2002), dan } \\
\text { Ariama (2018). }\end{array}$ & Likert \\
\hline
\end{tabular}

Sumber: Referensi terkait.

\section{Hasil Olah Data}

PLS digunakan dalam penelitian ini untuk melakukan analisis persamaan struktural berbasis varian yang secara simultan dapat melakukan pengujian model, yaitu pengukuran sekaligus pengujian model struktural (Ghozali, 2014). Model pengukuran (outer model) digunakan untuk mendapatkan uji validitas dan reliabilitas konstrak. Selanjutnya, pengujian model struktural (inner model) digunakan untuk memperoleh nilai R-square untuk konstrak dependen, Stone-Geisser $Q$-Square test untuk predictive relevance, dan uji t serta signifikansi dari koefisien parameter jalur struktural yang digambarkan pada Gambar 2.

\section{Model Pengukuran (Outer Model)}

Outer model menjelaskan bagaimana setiap blok indikator berhubungan dengan variabel latennya (Ghozali, 2014). Outer Model dengan indikator refleksif dievaluasi menggunakan convergent dan discriminant validity dari indikatornya dan composite 
reliability untuk blok indikator (Ghozali, 2014). Hasil masing-masing uji validitas diuraikan sebagai berikut:

\section{Validitas Konvergen (Convergent Validity)}

Convergent validity dapat dilihat dari korelasi antara score butir/indikator dengan score konstraknya. Indikator individu dianggap valid, jika nilai korelasi lebih besar atau sama dengan 0,50 (Ghozali, 2014). Tabel 5 memperlihatkan nilai hasil Outer Loading.

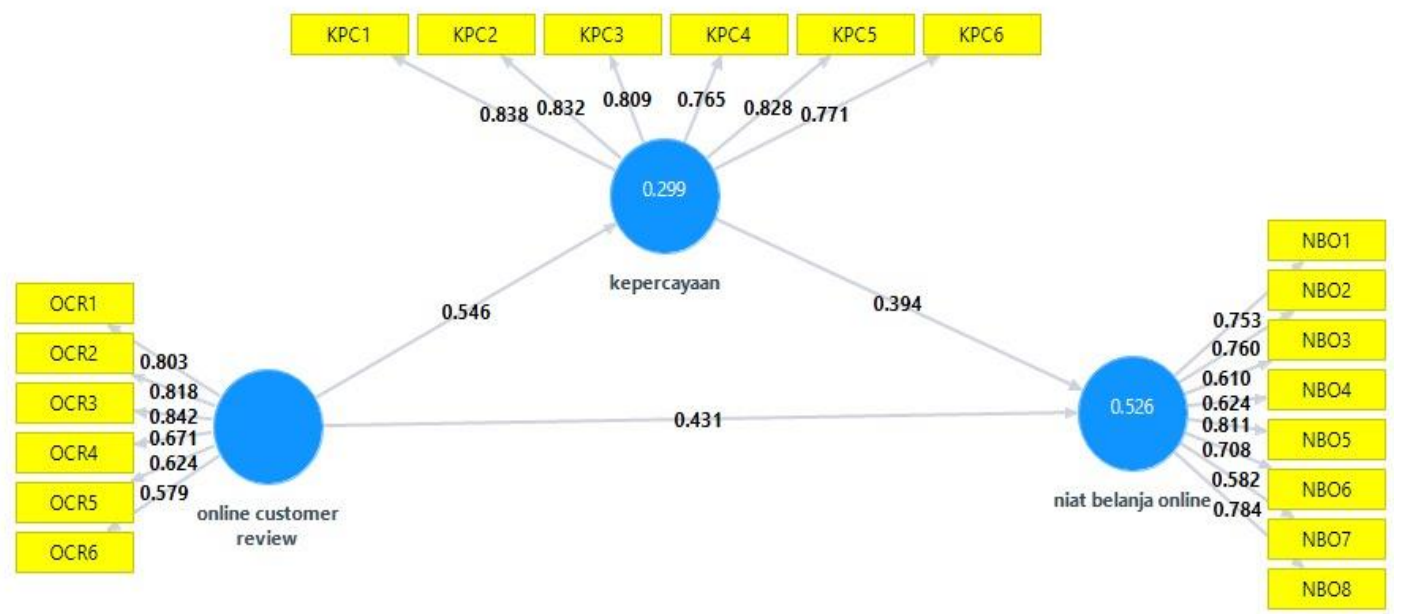

Sumber: Pengolahan data dengan PLS (2019).

Gambar 2. Hasil Analisis PLS Algorithm

Berdasarkan perhitungan data pada Tabel 5, apabila mengacu pada nilai outer loading awal yang disyaratkan sebesar 0,50 , maka semua butir pernyataan pada penelitian ini telah memenuhi persyaratan, yaitu nilai masing-masing outer loading untuk setiap butir pernyataan telah lebih dari 0,50 , sehingga semua butir pernyataan yang digunakan dinyatakan valid (Ghozali, 2014).

Tabel 5. Hasil pengujian Convergent Validity

\begin{tabular}{lcc}
\hline \multicolumn{1}{c}{ Variabel } & Item Pernyataan & Outer Loading \\
\hline Kepercayaan konsumen & 6 & 0,765 sampai 0,838 \\
\hline Niat belanja online & 8 & 0,582 sampai 0,811 \\
\hline Online customer review & 6 & 0,579 sampai 0,842 \\
\hline
\end{tabular}

Sumber: Pengolahan data dengan PLS (2019).

\section{Validitas Diskriminan (Discriminant Validity)}

Pengujian discriminant validity dapat dilakukan dengan cara melihat discriminant validity pada model pengukuran dengan indikator refleksif yang dinilai berdasarkan cross-loading pengukuran konstrak. Hasil pengujian discriminant validity ditunjukkan pada Tabel 6. Dari hasil pengujian discriminant validity tersebut, korelasi konstrak online customer review, kepercayaan konsumen, dan niat belanja online dengan indikatornya lebih tinggi daripada dengan korelasi antara indikatornya dengan konstrak lainnya. Hasil ini menunjukkan bahwa konstrak setiap variabel penelitian mampu mempre- 
diksi indikator pada blok mereka lebih baik daripada dengan indikator di blok lainnya (Ghozali, 2014).

Tabel 6. Butir Hasil Pengujian Discriminant Validity Berdasarkan Cross Loading

\begin{tabular}{cccc}
\hline Butir Instrumen & $\begin{array}{c}\text { Kepercayaan } \\
\text { Konsumen }\end{array}$ & $\begin{array}{c}\text { Niat Belanja } \\
\text { Online }\end{array}$ & $\begin{array}{c}\text { Online Customer } \\
\text { Review }\end{array}$ \\
\hline KPC1 & $\mathbf{0 , 8 3 8}$ & 0,526 & 0,478 \\
KPC2 & $\mathbf{0 , 8 3 2}$ & 0,508 & 0,473 \\
KPC3 & $\mathbf{0 , 8 0 9}$ & 0,462 & 0,403 \\
KPC4 & $\mathbf{0 , 7 6 5}$ & 0,486 & 0,317 \\
KPC5 & $\mathbf{0 , 8 2 8}$ & 0,548 & 0,469 \\
KPC6 & $\mathbf{0 , 7 7 1}$ & 0,512 & 0,483 \\
NBO1 & 0,488 & $\mathbf{0 , 7 5 3}$ & 0,548 \\
NBO2 & 0,400 & $\mathbf{0 , 7 6 0}$ & 0,461 \\
NBO3 & 0,396 & $\mathbf{0 , 6 1 0}$ & 0,257 \\
NBO4 & 0,273 & $\mathbf{0 , 6 2 4}$ & 0,426 \\
NBO5 & 0,590 & $\mathbf{0 , 8 1 1}$ & 0,527 \\
NBO6 & 0,418 & $\mathbf{0 , 7 0 8}$ & 0,430 \\
NBO7 & 0,475 & $\mathbf{0 , 5 8 2}$ & 0,343 \\
NBO8 & 0,471 & $\mathbf{0 , 7 8 4}$ & 0,582 \\
\hline OCR1 & 0,381 & 0,491 & $\mathbf{0 , 8 0 3}$ \\
OCR2 & 0,450 & 0,461 & $\mathbf{0 , 8 1 8}$ \\
OCR3 & 0,409 & 0,552 & $\mathbf{0 , 8 4 2}$ \\
OCR4 & 0,384 & 0,409 & $\mathbf{0 , 6 7 1}$ \\
OCR5 & 0,301 & 0,382 & $\mathbf{0 , 6 2 4}$ \\
OCR6 & 0,437 & 0,494 & $\mathbf{0 , 5 7 9}$ \\
\hline
\end{tabular}

Keterangan:

KPC (kepercayaan konsumen), NBO (niat belanja online), OCR (online customer review).

Sumber: Pengolahan data dengan PLS (2019).

Metode lain untuk menilai discriminant validity adalah membandingkan nilai square root of Average Variance Extracted (AVE) setiap konstrak dengan korelasi antara satu konstrak dengan konstrak lainnya di dalam model. Hasil validitas diskriminan berdasarkan AVE ditunjukkan pada Tabel 7.

Tabel 7. Hasil Pengujian Discriminant Validity Menggunakan Akar Kuadrat AVE yang Dilihat pada Hasil Pengujian Fornell-Larcker Criterium

\begin{tabular}{lccc}
\hline \multicolumn{1}{c}{ Variabel } & $\begin{array}{c}\text { Kepercayaan } \\
\text { Konsumen }\end{array}$ & $\begin{array}{c}\text { Niat Belanja } \\
\text { Online }\end{array}$ & $\begin{array}{c}\text { Online Customer } \\
\text { Review }\end{array}$ \\
\hline Kepercayaan konsumen & 0,808 & - & - \\
\hline Niat belanja online & 0,629 & 0,709 & - \\
\hline Online customer review & 0,546 & 0,646 & 0,730 \\
\hline
\end{tabular}

Sumber: Pengolahan data dengan PLS (2019).

Hasil pengujiannya menjelaskan bahwa nilai AVE pada variabel penelitian memiliki nilai di atas 0,50. Selanjutnya, jika dilihat dari nilai akar kuadrat AVE setiap konstrak yang terdiri atas akar AVE konstrak kepercayaan, niat belanja online, dan online 
customer review diperoleh nilainya lebih besar daripada nilai korelasi antarkonstrak dengan konstrak lainnya di dalam model, sehingga hasil tersebut memiliki discriminant validity yang baik (Ghozali, 2014).

\section{Reliabilitas Konstrak (Construct Reliability)}

Hasil pengolahan data penelitian untuk reliabilitas konstrak diukur menggunakan composite reliability dan Cronbach's alpha. Hasil pengolahan reliabilitas konstrak disajikan pada Tabel 8.

Tabel 8. Composite Reliability dan Cronbach's Alpha

\begin{tabular}{lcc}
\hline \multicolumn{1}{c}{ Variabel } & $\begin{array}{c}\text { Composite } \\
\text { Reliability }\end{array}$ & $\begin{array}{c}\text { Cronbach's } \\
\text { Alpha }\end{array}$ \\
\hline Kepercayaan konsumen & 0,918 & 0,893 \\
\hline Niat belanja online & 0,888 & 0,856 \\
\hline Online customer review & 0,870 & 0,818 \\
\hline
\end{tabular}

Sumber: Pengolahan data dengan PLS (2019).

Hasil pengolahan data menunjukkan bahwa nilai composite reliability dan Cronbach's alpha untuk semua konstrak kepercayaan konsumen, niat belanja online, dan online customer review lebih dari 0,70. Hasil tersebut menunjukkan bahwa semua konstrak pada model penelitian yang diestimasi telah memenuhi kriteria reliable, konstrak dinyatakan reliable, apabila nilai composite reliability maupun Cronbach's alpha di atas 0,70 (Ghozali, 2014).

\section{Pengujian Model Struktural (Inner Model)}

\section{Hasil estimasi R-square dan Q-square}

Pengolahan data penelitian ini memperoleh hasil estimasi R-square seperti yang ditunjukkan pada Tabel 9. Nilai R-square yang ditunjukkan pada Tabel 9 menunjukkan bahwa variabel ke-percayaan konsumen dapat dijelaskan oleh OCR sebesar 0,299 atau $29,9 \%$, sedangkan $70,1 \%$ dijelaskan oleh variabel lain di luar variabel yang diteliti. Selanjutnya, variabel niat belanja online dapat dijelaskan oleh OCR dan kepercayaan konsumen sebesar 0,526 atau 52,6\%, sedangkan 47,4\% dijelaskan oleh variabel lain di luar variabel yang diteliti. Di samping untuk mendapatkan nilai R-square, model penelitian ini juga dievaluasi menggunakan Q-square predictive relevance untuk model konstraknya. Q-square mengukur seberapa baik nilai observasi dihasilkan oleh model dan juga estimasi parameternya (Chin dalam Ghozali, 2014). Perhitungan Q-square ditunjukkan dalam formula pada persamaan [2].

Tabel 9. R-square

\begin{tabular}{lc}
\hline \multicolumn{1}{c}{ Variabel } & R-Square \\
\hline Kepercayaan konsumen & 0,299 \\
\hline Niat belanja online & 0,526 \\
Sumber: Pengolahan data menggunakan PLS (2019). &
\end{tabular}




$$
\begin{aligned}
& \mathbf{Q}^{\mathbf{2}}=\mathbf{1}-\left(\mathbf{1}-\mathbf{R}_{\mathbf{1}}{ }^{2}\right)\left(\mathbf{1}-\mathbf{R}_{2}{ }^{2}\right) \ldots \ldots \ldots\left(\mathbf{1}-\mathbf{R p}^{2}\right) \\
& \mathrm{Q}^{2}=1-\left(1-\mathrm{R}_{1}{ }^{2}\right)\left(1-\mathrm{R}_{2}{ }^{2}\right) \ldots \ldots \ldots\left(1-\mathrm{Rp}^{2}\right) \\
& \mathrm{Q}^{2}=1-\left(1-\mathrm{R}^{2}\right)\left(1-\mathrm{R}^{2}\right) \ldots \ldots \ldots .\left(1-\mathrm{Rp}^{2}\right) \\
& \mathrm{Q}^{2}=1-(1-0,299)(1-0,526) \\
& \mathbf{Q}^{2}=\mathbf{0 , 6 6 8}
\end{aligned}
$$

Hasil Q-square tersebut menunjukkan bahwa nilai relevansi prediksi sebesar 0,668 . Nilai tersebut lebih besar daripada 0 , yaitu $66,8 \%$ variasi pada variabel niat belanja online dapat dijelaskan oleh variabel yang digunakan pada model penelitian ini, sedangkan 33,2\% sisanya dijelaskan oleh faktor-faktor lainnya di luar model penelitian. Dengan hasil ini, maka model penelitian ini memiliki nilai relevansi prediksi yang baik.

\section{Pengujian Hipotesis dan Pembahasan}

Hipotesis dalam penelitian ini diuji menggunakan uji t. Hipotesis akan diterima apabila nilai t-statistics melebihi nilai t-tabel untuk derajat sinifikansi 0,05 sebesar 1,96 (Ghozali, 2014).

\section{Pengaruh Langsung}

Pengujian data untuk medapatkan nilai koefisen dan nilai signifikansi t-statistics pengaruh langsung menggunakan pengujian dengan langkah bootstrapping pada program PLS (Ghozali, 2014). Bootstrapping merupakan pilihan perintah pada tampilan program PLS yang hasilnya ditunjukkan pada Tabel 10.

Tabel 10. Hasil Path-Coefficients dengan Metode PLS Pengaruh Langsung

\begin{tabular}{lccccc}
\hline \multicolumn{1}{c}{$\begin{array}{c}\text { Hubungan } \\
\text { Antarvariabel }\end{array}$} & $\begin{array}{c}\text { Original } \\
\text { Sample }(\mathbf{O})\end{array}$ & $\begin{array}{c}\text { Sample } \\
\text { Mean }(\mathbf{M})\end{array}$ & $\begin{array}{c}\text { Standard Error } \\
\text { (STERR) }\end{array}$ & $\begin{array}{c}\text { t-Statistics } \\
(\mid \mathbf{O} \text { /STERR|) }\end{array}$ & $\begin{array}{c}\text { p- } \\
\text { values }\end{array}$ \\
\hline $\begin{array}{l}\text { Kepercayaan konsumen } \\
\rightarrow \text { Niat belanja online }\end{array}$ & 0,394 & 0,395 & 0,080 & 4,915 & 0,000 \\
\hline $\begin{array}{l}\text { Online customer review } \rightarrow \\
\text { Kepercayaan konsumen }\end{array}$ & 0,546 & 0,558 & 0,067 & 8,146 & 0,000 \\
\hline $\begin{array}{l}\text { Online customer review } \rightarrow \\
\text { Niat belanja } \text { online }\end{array}$ & 0,431 & 0,435 & 0,074 & 5,786 & 0,000 \\
\hline
\end{tabular}

Sumber: Pengolahan data dengan PLS (2019).

Berdasarkan hasil pengujian tersebut, maka pengaruh langsung variabel penelitian ini dapat diuraikan sebagai berikut:

\section{a. Pengaruh Online Customer Review terhadap Kepercayaan Konsumen}

Hasil pengujian hipotesis kesatu (H1) menunjukkan bahwa OCR mempunyai pengaruh positif dan signifikan terhadap kepercayaan konsumen pada toko online Bukalapak di Kota Padang dengan nilai uji t-statistics $>1,96$, yaitu 8,146 dan tingkat signifikansi yang ditunjukkan melalui hasil p-values $0,000<0,05$. Nilai path-coefficient OCR bernilai positif sebesar 0,546. Dengan demikian, variabel OCR mempengaruhi kepercayaan konsumen pada toko online Bukalapak di Kota Padang. Semakin baik OCR, maka semakin meningkat pula kepercayaan konsumen pada toko online Bukalapak di Kota Padang.

Hasil ini mengindikasikan OCR merupakan variabel penting yang diperhatikan konsumen dan mempengaruhi tingkat kepercayaannya dalam berbelanja online di 
toko online Bukalapak di Kota Padang. OCR yang berisi informasi tentang Bukalapak memudahkan konsumen berbelanja online dan mencari maupun menemukan informasi tentang produknya. Selain itu, layanan OCR tentang Bukalapak tidak membingungkan konsumen dan mereka merasa mudah memahaminya, sehingga informasi tersebut mempengaruhi kepercayaan mereka. Selanjutnya, konsumen juga merasa lebih mampu mengendalikan belanja online, ketika mereka membaca komentar pelanggan secara online di Bukalapak. Selain itu, komentar-komentar konsumen lain juga memberikan lebih banyak kontrol kepada calon konsumen atas proses layanan di Bukalapak, sehingga konten-konten tersebut mempengaruhi kepercayaan konsumen pada toko online Bukalapak di Kota Padang.

Hasil penelitian ini konsisten dengan hasil penelitian Kanitra dan Kusumawati (2018) yang menemukan adanya pengaruh signifikan variabel online costumer review terhadap variabel trust. Demikian pula, hasil tersebut senada dengan hasil penelitian Elwalda dan Lü (2014) yang menemukan bahwa online customer review berpengaruh pada kepercayaan dan niat beli konsumen.

\section{b. Pengaruh Online Customer Review terhadap Niat Belanja Online}

Berdasarkan hasil pengujian hipotesis kedua (H2), OCR mempunyai pengaruh positif dan signifikan terhadap niat belanja online konsumen di toko online Bukalapak di Kota Padang dengan nilai uji t-statistics $>1,96$, yaitu 5,786 dan p-values $0,000<0,05$. Nilai path-coefficient OCR bernilai positif sebesar 0,431. Dengan demikian, OCR merupakan variabel yang mempengaruhi niat belanja online konsumen di toko online Bukalapak di Kota Padang. Artinya, semakin baik OCR, maka semakin meningkat niat belanja online konsumen di toko online Bukalapak di Kota Padang.

Hasil tersebut mengindikasikan bahwa niat belanja online konsumen di toko online Bukalapak di Kota Padang dipengaruhi oleh OCR yang dilakukan konsumen Bukalapak sebelumnya. OCR yang dilakukan para konsumen sebelumnya memudahkan calon konsumen lainnya untuk berbelanja online serta mencari dan menemukan informasi tentang produknya. Selain itu, layanan OCR yang diberikan konsumen mampu menjadi referensi bagi calon konsumen agar tidak membingungkan dan mereka merasa mudah memahaminya, sehingga informasi tersebut dapat mempengaruhi niat belanja online mereka. Selanjutnya, konsumen juga merasa lebih mampu mengendalikan belanja online ketika mereka membaca komentar-komentar konsumen lainnya. Di samping itu, komentar-komentar konsumen tersebut juga memberikan lebih banyak kontrol atas proses layanan di Bukalapak, sehingga mempengaruhi niat belanja online mereka di toko online Bukalapak di Kota Padang.

Review merupakan bagian dari electronic word of mouth (eWOM) yaitu pendapat langsung seseorang dan bukan merupakan iklan perusahaan. Review adalah salah satu dari beberapa faktor yang menentukan keputusan pembelian seseorang (Lee \& Shin, 2014). Hal tersebut menunjukkan bahwa seseorang dapat menggunakan jumlah review sebagai indikator popularitas produk atau nilai suatu produk yang dapat mempengaruhi niat mereka untuk membeli produk tersebut.

Hasil penelitian ini konsisten dengan penelitian Ichsan (2018) yang menemukan variabel consumer online rating and review berpengaruh secara signifikan terhadap minat beli konsumen. Begitu juga dengan hasil penelitian Farki et al. (2016) yang menemukan bahwa review dan rating terbukti memiliki pengaruh yang signi- 
fikan terhadap minat beli pelanggan pada online marketplace. Hasil penelitian ini konsisten dengan penelitian Elwalda dan Lü (2014) yang menemukan bahwa online customer review berpengaruh terhadap minat beli konsumen.

\section{c. Pengaruh Kepercayaan Konsumen terhadap Niat Belanja Online}

Berdasarkan hasil pengujian hipotesis ketiga (H3) menunjukkan bahwa kepercayaan konsuen mempunyai pengaruh positif dan signifikan terhadap niat belanja online konsumen di toko online Bukalapak di Kota Padang. Dengan nilai uji t-statistics $>1,96$, yaitu 4,915 dan p-values $0,000<0,05$. Nilai path-coefficient kepercayaan konsumen bernilai positif sebesar 0,394. Hasil tersebut menunjukkan bahwa kepercayaan konsumen merupakan variabel yang mempengaruhi niat belanja online konsumen di toko online Bukalapak di Kota Padang. Artinya, semakin baik kepercayaan konsumen, maka niat belanja online konsumen semakin meningkat di toko online Bukalapak di Kota Padang.

Hasil ini mengindikasikan bahwa kepercayaan konsumen terletak pada bentuk jaminan keuangan saat mereka melakukan transaksi pembelian di Bukalapak, serta mereka mendapatkan jaminan keamanan dalam melakukan pembayaran secara elektronik. Selanjutnya, kepercayaan konsumen pada Bukalapak ditentukan pula oleh jaminan privasi perlindungan data dan pengumpulan data pribadi konsumen dalam proses layanan transaksi di Bukalapak, serta kepercayaan mereka pada Bukalapak karena bertindak jujur dan dapat dipercaya dalam memberikan informasi belanja kepada konsumen. Bukalapak memiliki persediaan produk yang cukup memadai untuk menjamin transaksi belanja online. Kondisi tersebut menjadi hal penting yang diperhatikan konsumen dan mempengaruhi niat belanja online mereka di toko online Bukalapak di Kota Padang.

Hasil penelitian ini sejalan dengan penelitian Ikranegara (2017) yang menemukan bahwa ada pengaruh positif variabel kepercayaan konsumen terhadap minat beli secara online. Begitu pula dengan hasil penelitian Nurlina (2017) yang menemukan adanya pengaruh positif kepercayaan konsumen dengan minat beli konsumen. Hasil penelitian ini juga konsisten dengan penelitian Farki et al. (2016) yang menemukan bahwa trust terbukti memiliki pengaruh signifikan terhadap purchase intention.

\section{Pengaruh Tidak Langsung}

Pengujian data untuk mendapatkan nilai koefisen dan nilai signifikansi t-statistik pengaruh tidak langsung juga menggunakan pengujian dengan langkah bootstrapping pada program PLS (Ghozali, 2014). Bootstrapping merupakan pilihan perintah pada tampilan program PLS yang hasilnya ditampilkan pada Tabel 11.

\section{Pengaruh Online Customer Review terhadap Niat Belanja Online melalui Kepercayaan Konsumen}

Hasil pengujian hipotesis keempat (H4) menunjukkan bahwa OCR mempunyai peng-aruh positif dan signifikan terhadap niat beli melalui kepercayaan konsumen pada toko online Bukalapak di Kota Padang dengan nilai uji t-statistics $>1,96$, yaitu 4,249 dan p-values $0,000<0,05$. Dengan demikian, OCR berpengaruh positif dan signifikan terhadap niat belanja online konsumen pada toko online Bukalapak di Kota Padang melalui kepercayaan konsumen. Nilai path-coefficient pengaruh tidak langsung OCR terhadap niat belanja online melalui kepercayaan konsumen sebesar 0,215 yang ditunjukkan pada Tabel 11. Hasil ini membuktikan bahwa kepercayaan konsumen sebagai variabel inter- 
vening memperkuat pengaruh OCR terhadap niat belanja online, karena jika OCR meningkat, maka hal itu akan meningkatkan kepercayaan konsumen, dan kepercayaan konsumen juga akan meningkatkan niat belanja online.

Tabel 11. Hasil Path-Coefficients Metode PLS Pengaruh Tidak Langsung

\begin{tabular}{lccccc}
\hline Hubungan Antarvariabel & $\begin{array}{c}\text { Original } \\
\text { Sample }(\mathbf{O})\end{array}$ & $\begin{array}{c}\text { Sample } \\
\text { Mean }(\mathbf{M})\end{array}$ & $\begin{array}{c}\text { Standard Error } \\
(\text { STERR })\end{array}$ & $\begin{array}{c}\text { t-Statistics } \\
(\mid \mathbf{O} \text { /STERR })\end{array}$ & $\begin{array}{c}\text { p- } \\
\text { values }\end{array}$ \\
\hline $\begin{array}{l}\text { Kepercayaan konsumen } \rightarrow \\
\text { Niat belanja online }\end{array}$ & - & - & - & - & - \\
\hline $\begin{array}{l}\text { Online customer review } \rightarrow \\
\text { Kepercayaan konsumen }\end{array}$ & - & - & - & - & - \\
\hline $\begin{array}{l}\text { Online customer review } \rightarrow \\
\text { Niat belanja online }\end{array}$ & 0,215 & 0,220 & 0,051 & 4,249 & 0,000 \\
\hline
\end{tabular}

Sumber: Pengolahan data dengan PLS (2019).

Hasil tersebut juga mengindikasikan bahwa konsumen lebih cenderung menggunakan OCR untuk mengurangi rasa ketidakpastian konsumen terhadap produk yang ditawarkan toko online Bukalapak di Kota Padang. Dengan adanya OCR, gambaran lebih nyata diberikan terhadap produk yang ditawarkan oleh Bukalapak. OCR merupakan sumber informasi utama bagi konsumen. Informasi yang diperoleh konsumen dapat menciptakan opini terhadap produk maupun layanan jasa yang ditawarkan, sehingga hal itu akan memicu munculnya kepercayaan konsumen. Semakin baik review yang diberikan konsumen lain terhadap produk, maka kepercayaan konsumen terhadap produk juga akan semakin meningkat. Konten online review yang baik dapat menjadi informasi yang menimbulkan kepercayaan konsumen, sehingga peningkatan kepercayaan akan meningkatkan niat belanja online konsumen.

Hasil penelitian ini konsisten dengan hasil penelitian Elwalda dan Lü (2014) yang menemukan online customer review berpengaruh pada kepercayaan konsumen dan niat belanja online mereka. Penelitian ini juga didukung oleh penelitian Kanitra dan Kusumawati (2018) yang menemukan OCR berpengaruh signifikan terhadap variabel kepercayaan. Selanjutnya, hasil penelitian ini juga sama dengan penelitian yang dilakukan Ikranegara (2017) dan Nurlina (2017), yaitu adanya pengaruh positif kepercayaan konsumen terhadap niat belanja online. Demikian pula, hasilnya mendukung hasil penelitian Farki et al. (2016) yang menemukan bahwa trust terbukti memiliki pengaruh signifikan terhadap purchase intention.

\section{KESIMPULAN DAN SARAN}

\section{Kesimpulan}

Berdasarkan hasil penelitian, maka hasil yang diperoleh OCR berpengaruh positif dan signifikan terhadap kepercayaan konsumen, sedangkan OCR dan kepercayaan konsumen berpengaruh positif dan signifikan terhadap niat belanja online konsumen, serta OCR berpengaruh positif dan signifikan terhadap niat belanja online melalui kepercayaan konsumen. Hasil ini mengindikasikan bahwa semakin baik review yang didapatkan calon konsumen dari konsumen lain, maka hal itu akan mempengaruhi niat belanja online mereka untuk berbelanja, baik secara langsung maupun melalui kepercayaan mereka. Review yang diterima konsumen dan disediakan pada setiap mitra pela- 
pak akan menjadi pertimbangan penting untuk membangun sebuah kepercayaan. Kepercayaan konsumen dapat digunakan sebagai dasar bagi keberhasilan sebuah transaksi secara online. Hal itu dikarenakan konsumen yang berbelanja online tidak dapat berinteraksi secara langsung dengan barang yang dibutuhkan. Mereka hanya melihat berdasarkan apa yang ditampilkan pada situs belanja online, sehingga agar calon konsumen memiliki niat belanja online pada situs Bukalapak di Kota Padang, maka Bukalapak harus mampu membangun kepercayaan yang tinggi pada calon konsumennya.

\section{Saran}

Untuk meningkatkan niat belanja online konsumen di situs belanja online, maka Bukalapak maupun para mitra pelapak disarankan untuk memperbaiki online customer review. Salah satu caranya adalah menanggapi komentar yang diberikan konsumen sesegera mungkin pada kolom komentar, baik yang berhubungan langsung dengan produk yang ditawarkan maupun layanan yang diberikan. Di sisi lain, untuk memperbaiki kepercayaan konsumen, maka Bukalapak dan para mitra pelapak disarankan pula untuk memberikan produk kepada konsumen sesuai dengan produk aslinya. Selanjutnya, Bukalapak perlu menampilkan gambar produknya sendiri dan sesuai dengan produk yang diterimakan kepada konsumennya.

\section{DAFTAR REFERENSI}

Ariama, C. (2018). Pengaruh Iklan dan Word of Mouth terhadap Minat Belanja Online dengan Aplikasi Lazada (Studi Kasus pada Mahasiswa FISIP Adminstrasi Bisnis 2014-2017 Universitas Mulawarman). eJournal Administrasi Bisnis, 6(2), 487497.

Anisa, R. (2019). Pergaulan Bebas Zaman Globalisasi. 31 Maret 2019. Diakses Februari 2020 dari http://anisaromirilanti.blogspot.com/2019/03/plagiat-dalam-internet. html.

Auliya, Z. F., Umam, M. R. K., \& Prastiwi, S. K. (2017). Online Costumer Reviews (OTRs) dan Rating: Kekuatan Baru pada Pemasaran Online di Indonesia. Jurnal EBBANK, 8(1), Juni, 89-98.

Baskara, I. P. \& Hariyadi, G. T. (2014). Analisis Pengaruh Kepercayaan, Keamanan, Kualitas Pelayanan dan Persepsi akan Resiko tehadap Keputusan Pembelian melalui Situs Jejaring Sosial (Social networking Websites). Skripsi. Fakultas Ekonomi, Universitas Dian Nuswantoro, Semarang.

Chou, S. Y. (2012). Online Reviews and Pre-Purchase Cognitive Dissonance: A Theoretical Framework and Research Propositions. Journal of Emerging Trends in Computing and Information Sciences, 3(2), 199-204.

Elwalda, E. \& Lü, K. (2014). The Influence of Online Customer Reviews on Purchase Intention: The Role of Non-numerical Factors. European Marketing Conference LCBR 1-13, at Munich, Germany

Farki, A., Baihaqi, I., \& Wibawa, B. M. (2016). Pengaruh Online Customer Review dan Rating terhadap Kepercayaan dan Minat Pembelian pada Online Marketplace di Indonesia. Jurnal Teknik ITS, 5(2), 614-619.

Ferdinand, A. (2002). Pengembangan Minat Beli Merek Ekstensi. Semarang: Badan Penerbit Universitas Diponegoro. 
Ferrinadewi, E. (2008). Merek \& Psikologi Konsumen: Implikasi pada Strategi Pemasaran. Yogyakarta: Graha Ilmu.

Filieri, R. (2014). What Makes Online Reviews Helpful? A Diagnosticity-adoption Framework to Explain Informational and Normative Influences in e-WOM. Journal of Business Research, 68(6), 1261-1270.

Ghozali, I. (2014). Structural Equation Modeling Metode Alternatif dengan Partial Least Square (PLS) Dilengkapi Software SmartPLS 3.00 Xistat 2014 dan WarpPLS 4.0. Edisi ke-4. Semarang: Badan Penerbit Universitas Diponegoro Semarang.

Hennig-Thurau, T., Gwinner, K. P., Walsh, G. \& Gremler, D. D. (2004). Electronic Word-of-mouth via Consumer-opinion Platforms: What Motivates Consumers to Articulate Themselves on the Internet? Journal of Interactive Marketing, 18(1), $38-52$.

Picaully, M. R. 2018. Pengaruh Kepercayaan Pelanggan terhadap Niat Pembelian Gadget di Shopee Indonesia. Jurnal Manajemen Maranatha, 18(1), November, $31-40$.

Ichsan, M. (2018). Pengaruh Consumer Online Rating and Review terhadap Minat Beli Konsumen pada Marketplace Tokopedia di Wilayah DKI Jakarta. e-Proceeding of Management, 5(2), Agustus, 1828-1835.

Ikranegara, D. P. (2017). Pengaruh Orientasi Belanja, Kepercayaan Online, dan Pengalaman Pembelian terhadap Minat Beli secara Online (Studi Kasus pada Toko Online Bukalapak). Skripsi. Fakultas Ekonomi, Universitas Negeri Yogyakarta.

inet.detik.com, 2019. Achmad Zaky, Anak Desa yang Sukses Bikin Bukalapak Meraksasa 15 Februari 2019, 11.30 WIB, diakses 2020 dari https://inet.detik. com/cyberlife/d-4429366/achmad-zaky-anak-desa-yang-sukses-bikin-bukalapakmeraksasa.

Iprice.co.id (2019). Peta E-Commerce Indonesia. Diakses Juni 2019 dari https://iprice. co.id/insights/mapofecommerce/.

Kanitra, A. R. \& Kusumawati, A. (2018). Pengaruh Country of Origin dan Online Consumer Review terhadap Trust dan Keputusan Pembelian (Survei pada Mahasiswa S1 Fakultas Ilmu Administrasi Universitas Brawijaya Angkatan 2015/2016 dan 2016/2017 Tahun Akademik 2017/2018 Pembeli Produk Oppo Smartphone). Jurnal Administrasi Bisnis (JAB), 61(1), 64-73.

Kerin, R. A., Lau, G. T., Hartley, S. W. \& Rudelius, W. (2009). Marketing in Asia. Singapore: McGraw-Hill, Inc.

Khan, M. S., Naumann, E. \& Williams, P. (2012). Identifying the Key Drivers of Customer Satisfaction and Repurchase Intentions: An Empirical Investigation of Japanese B2B Services. Journal of Consumer Satisfaction, Dissatisfaction and Complaining Behavior, 25, 159-178

Kotler, P. \& Keller, K. L. (2016). Marketing Management. 15th Edition. New York: Pearson Education, Inc.

Lackermair, G., Kailer, D., \& Kanmaz, K. (2013). Importance of Online Product Reviews from a Consumer's. Perspective., 1(1), 1-5. 
Lee, M. \& Youn, S. (2009). Electronic Word of Mouth (eWOM): How eWOM Platforms Influence Consumer Product Judgement. International Journal of Advertising, 28(3), 473-499.

Lee, K. \& Koo, D. (2012). Effects of Attribute and Valence of e-WOM on Message Adoption: Moderating Roles of Subjective Knowledge and Regulatory Focus. Computers in Human Behavior, 28(5), 1974-1984. DOI: http://dx.doi.org/10. 1016/j.chb.2012.05.018.

Lee, E.-J. \& Shin, S. Y. (2014). When do Consumers Buy Online Product Reviews? Effects of Review Quality, Product Type, and Reviewer's Photo. Computers in Human Behavior, 31, 356-366.

Ling, K. C., Chai, L. T., \& Piew, T. H. (2010). The Effects of Shopping Orientation, Online Trust and Prior Online Purchase Experience toward Customers' Online Purchase Intention. International Business Research, 3(3), 63-76

Liu, Y. (2006). Word of Mouth for Movies: Its and Impact on Box Office Dynamics Revenue. Journal of Marketing, 70(3), 74-89. Retrieved from http://www.jstor. org/stable/30162102.

Mo, Z. L. Y. \& Fan, P. (2015). Effect of Online Reviews on Consumer Purchase Behavior. Journal of Service Science and Management, 8(June), 419-424.

Mowen, J. C. \& Minor, M. (2002). Perilaku Konsumen. Edisi Kelima (Jilid 2). Jakarta: Penerbit Erlangga.

Nurlina (2017). Pengaruh E-Service Quality dan Kepercayaan Online terhadap Minat Pembelian Toko Online di Tokopedia. Jurnal Lentera Bisnis, 6(2), November, 83-93.

Park, C. \& Lee, T. M. (2009). Information Direction, Website Reputation and eWOM Effect: A Moderating Role of Product Type. Journal of Business Research, 62(1), 61-67. DOI: http://dx.doi.org/10.1016/j.jbusres.2007.11.017.

Penitasari, N. (2017). Pengaruh Harga dan Kualitas Produk terhadap Minat Beli Abon Lele Bang Zay (Studi pada Konsumen Abon Lele Bang Zay di Kota Malang). Thesis. University of Muhammadiyah Malang.

Rusli, H. (2015). Kebijakan bukalapak.com Berpihak Kepada Pelapak Penipu. Diakses Maret 2019 dari https://lapor.net.

Sarwono, J. (2012). Metode Riset Skripsi Pendekatan Kuantitatif Menggunakan Prosedur SPSS: Tuntunan Praktis dalam Menyusun Skripsi. Jakarta: Elex Media Komputindo.

Setiadi, N. J. (2010). Perilaku Konsumen: Perspektif Kontemporer pada Motif, Tujuan, dan Keinginan Konsumen. Edisi Revisi, Cetakan ke-4. Jakarta: Kencana.

Simamora, B. (2011). Memenangkan Pasar dengan Pemasaran Efektif dan Profitabel. Jakarta: PT Gramedia Pustaka Utama.

Sugiyono (2014). Metode Penelitian Bisnis. Bandung: Alfabeta.

Sumarwan, U. (2011). Perilaku Konsumen: Teori dan penerapannya dalam Pemasaran. Bogor: Ghalia Indonesia.

Sophia, I. (2014). Pengaruh Orientasi Belanja, Kepercayaan Online, dan Pengalaman Pembelian Sebelumnya terhadap Minat Beli Pelanggan secara Online pada Mahasiswa/i Fakultas Ekonomi Universitas Syiah Kuala. Skripsi. Fakultas Ekonomi Universitas Syiah Kuala Darussalam, Banda Aceh. 
Widyawati, N. (2008). Pengaruh Kepercayaan dan Komitmen serta Bauran Pemasaran Jasa terhadap Loyalitas Konsumen di Hotel Zakiah Medan. Jurnal Ekuitas, 12(1), Maret, 74-96.

Yasmin, A., Tasneem, S., \& Fatema, K. (2015). Effectiveness of Digital Marketing in the Challenging Age: An Empirical Study. International Journal of Management Science and Business Administration, 1(2), 69-80. Retrieved from http://researchleap.com/category/international.

Zafar, Q. U. A. \& Rafique, Mahira (2013). Impact of Celebrity Advertisement on Customers Brand Perception and Purchase Intention. Asian Journal of Business and Management Sciences, 1(11), 53-67.

Zhu, F. (2010). Impact of Online Consumer Reviews on Sales: The Moderating Role of Product and Consumer. Journal of Marketing, 74(March), 133-148.

Zhu, F. \& Zhang, X. (Michael) (2010). Impact of Online Consumer Reviews on Sales: The Moderating Role of Product and Consumer Characteristics. Journal of Marketing, 74(March), 133-148. 